\title{
PENGARUH PENGGUNAAN FLY ASH ABU SERBUK KAYU DAN KAPUR TERHADAP KUAT GESER DAN DAYA DUKUNG TANAH LEMPUNG
}

\author{
Poni Yulianti ${ }^{1}$, Suradji Gandi ${ }^{2}$, dan Okrobianus Hendri ${ }^{3}$ \\ ${ }^{123}$ Program Studi Teknik Sipil, Fakultas Teknik, Universitas Palangka Raya \\ E-mail: poniyulianti3@gmail.com ${ }^{1}$, suradjigandi_ir@jts.upr.ac.id ${ }^{2}$, dan \\ okrobianus@jts.upr.ac.id ${ }^{3} / \mathbf{H P . + 6 2 8 2 3 5 0 3 9 5 1 8 5}{ }^{1}$
}

\begin{abstract}
ABSTRAK
Penelitian ini bertujuan untuk mendapatkan pengujian kuat geser langsung pada tanah lempung yang disubstitusi dengan material fly ash, abu serbuk kayu, dan kapur. Untuk itu pengujian ini dilakukan dengan campuran fly ash, abu serbuk kayu, dan kapur pada tanah lempung agar dapat dilihat seberapa kekuatan geser pada beban yang berada diatas tanah tersebut. Dalam penelitian ini menggunakan metode eksperimental, dan analitikal yaitu dengan mencari daya dukung dan kuat geser terhadap tanah lempung dengan campuran fly ash, abu serbuk kayu dan kapur. Untuk mengetahui pengaruh fly ash, abu serbuk kayu pada tanah lempung dengan peningkatan nilai sudut geser tanah $(\varnothing)$ tertinggi pada fly ash, abu serbuk kayu dan kapur 3 hari terdapat pada persentase campuran tanah $15 \%$ sebesar $=20^{\circ}$ dengan persentase kenaikan sebesar $=5,2 \%$ dari tanah asli dan pada fly ash, abu serbuk kayu dan kapur 7 hari pada campuran $15 \%$ sebesar $=21^{\circ}$ dengan persentase sebesar 2,9\% dari tanah asli. Sedangkan peningkatan nilai kohesi (c) tertinggi fly ash, abu serbuk kayu dan kapur 3 hari terdapat pada persentase campuran $10 \%$ sebesar $=$ $0,198 \mathrm{~kg} / \mathrm{cm}^{2}$ dengan persentase kenaikan sebesar $=0,8 \%$ dari tanah asli dan pada fly ash, abu serbuk kayu dan kapur 7 hari pada campuran $15 \%$ sebesar $=0,23 \mathrm{~kg} / \mathrm{cm}^{2}$ dengan persentase sebesar $=4 \%$ dari tanah asli.
\end{abstract}

Kata kunci: kuat geser daya dukung tanah, tanah lempung, uji geser langsung

\begin{abstract}
Ahmad Yani street is one of the urban roads in the city of Palangka Raya which has This study aims to obtain a direct shear strength test on clay soil which is substituted with fly ash, sawdust ash, and lime. For this reason, this test is carried out with a mixture of fly ash, sawdust ash, and lime on clay so that it can be seen how much the shear strength is in the load that is above the soil. In this study using experimental and analytical methods, namely by looking for the bearing capacity and shear strength of clay soil with a mixture of fly ash, sawdust ash and lime. To determine the effect of fly ash, sawdust ash on clay soil with the highest increase in soil shear angle ( $\phi)$ in fly ash, sawdust ash and lime for 3 days found in the percentage of soil mixture $15 \%$ of $=20^{\circ}$ with an increase in percentage of $=5,2 \%$ of the original soil and in fly ash, sawdust and lime for 7 days in a mixture of $15 \%$ $=21^{\circ}$ with a percentage of $2.9 \%$ of the original soil. Whereas the highest increase in cohesion value (c) of fly ash, sawdust ash and lime for 3 days was found in the percentage of $10 \%$ mixture of $=0.198 \mathrm{~kg} / \mathrm{cm}^{2}$ with an increase percentage of $=$ $0.8 \%$ from the original soil and in fly ash, sawdust ash and lime for 7 days in a $15 \%$ mixture of $=0.23 \mathrm{~kg} / \mathrm{cm}^{2}$ with a percentage of $=4 \%$ of the original soil.

Keyword : clay soil, direct shear test, shear strength soil bearing capacity
\end{abstract}




\section{PENDAHULUAN}

Dalam perencanaan dan pekerjaan suatu konstruksi bangunan sipil tanah mempunyai peranan yang sangat penting. Dalam hal ini, tanah berfungsi sebagai penahan beban akibat konstruksi di atas tanah yang harus bisa memikul seluruh beban bangunan. Sehingga kuat atau tidaknya bangunan/konstruksi itu juga dipengaruhi oleh kondisi tanah yang ada. Kondisi tanah pada suatu daerah tidak akan memiliki sifat tanah yang sama dengan daerah lainnya, Hanya tanah yang mempunyai stabilitas baik yang mampu mendukung konstruksi yang besar. Sedangkan tanah yang kurang baik harus distabilisasi terlebih dahulu sebelum dipergunakan sebagai pondasi pendukung dengan cara mencampur bahan pencampur seperti fly ash (abu terbang), abu serbuk kayu dan kapur. Penelitian ini dalam bentuk hubungan perubahan antara kuat geser dan daya dukung tanah lempung yang disubtitusi/dicampur dengan abu terbang (fly ash), abu serbuk kayu dan kapur.

\section{Tujuan Penelitian}

Tujuan dari penelitian ini adalah mengetahui sifat fisik dan mekanik tanah lempung pada Desa Bukit Rawi Kecamatan Kahayan, Kabupaten Pulang Pisau, Kalimantan Tengah, mengetahui proporsi campuran fly ash, abu serbuk kayu dan kapur terhadap daya dukung tanah lempung dari Desa Bukit Rawi, dan mengetahui pengaruh penggunaan fly ash, abu serbuk kayu dan kapur terhadap kuat geser dan daya dukung tanah lempung.

\section{METODE PENELITIAN}

\section{Lokasi Penelitian}

Penelitian ini dilakukan di Desa Bukit Rawi, Kecamatan Kahayan Tengah, Kabupaten Pulang Pisau, Kalimantan Tengah.

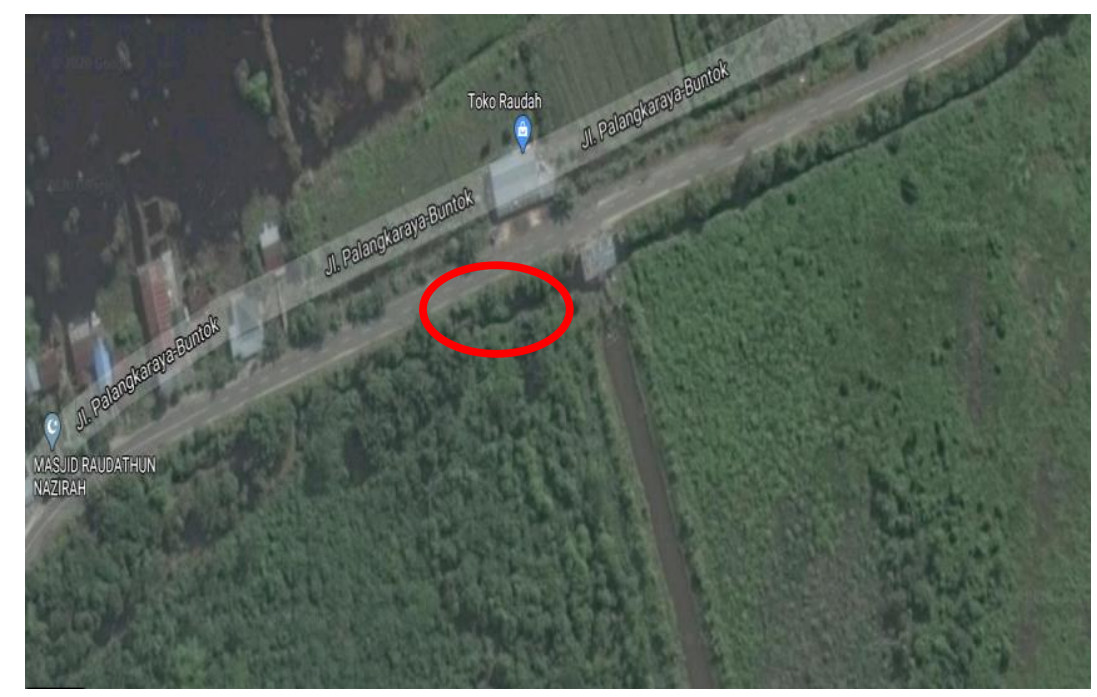

Gambar 1. Lokasi Pengambilan Sampel Tanah Sumber: www.googleearth.com 


\section{Tahap Pengambilan Sampel}

\section{Sampel Tanah}

Tanah yang akan digunakan untuk pengujian adalah jenis tanah lempung yang diambil dari Kota Banjarmasin, Kalimantan Selatan dengan cara pengambilan sampel yang dilakukan sebagai berikut:

a) Untuk contoh tanah asli (undisturb) diambil dari kedalaman kira-kira $50 \mathrm{~cm}$ di bawah permukaan tanah guna menghilangkan sisa-sisa kotoran tanah. Contoh tanah asli dapat diambil dengan memakai tabung contoh (samples tubes). Tabung contoh ini dimasukkan ke dalam dasar lubang bor. Tabung-tabung contoh yang biasanya dipakai memiliki diameter 6 sampai dengan $7 \mathrm{~cm}$.

b) Untuk contoh tanah terganggu (disturb), sampel tanah diambil secara bongkahan permukaan tanah.Kajian Pustaka Daya dukung tanah dan kuat geser tanah dengan hasil uji Laboratorium.

\section{Sampel fly ash}

Sampel fly ash bersumber dari PLTU di Desa Buntoi, Kecamatan Kahayan Hilir, Kabupaten Pulang Pisau, Kalimantan Tengah sebagai bahan tambah pada campuran tanah lempung asli untuk mencari kuat geser dan daya dukung tanah

\section{Sampel Abu Serbuk Kayu}

Sampel abu serbuk kayu yang di ambil dari salah satu meubel di jalan Beliang Palangka Raya, Kalimantan Tengah. Cara pengolahan serbuk kayu yaitu :

a) Menyiapkan serbuk kayu.

b) Serbuk kayu yang akan digunakan terlebih dahulu dikeringkan dibawah sinar matahari untuk mempermudah proses pembakaran.

c) Serbuk kayu yang telah kering kemudian dibakar dengan cara manual.

d) Pembakaran dilakukan selama \pm 2 jam hingga serbuk kayu berubah warna menjadi hitam keabu-abuan.

\section{Sampel kapur}

Kapur yang digunakan dalam penelitian ini, jenis kapur Tohor yang biasa digunakan sebagai bahan bangunan. Kapur telah banyak di teliti dalam pemanfaatannya sebagai bahan untuk perbaikan tanah dan hasilnya dapat meningkatkan daya dukung tanah. Untuk mengetahui pengaruh pencampuran kapur dengan tanah lempung maka dilakukan dengan cara membuat variasi pencampuran kapur sehingga mendapatkan nilai yang maksimal terhadap peningkatan kuat geser tanah dengan melakukan uji mekanis tanah lempung. sifat mekanis itu sendiri yaitu uji kuat geser tanah (direct shear).

\section{Tahap Pengujian Laboratorium}

Penelitian dilaksanakan di laboratorium untuk mengetahui sifat- sifat tanah seperti sifat fisik dan sifat mekanis dari tanah. Penelitian ini juga untuk mengetahui seberapa besar pengaruh yang dihasilkan setelah dilakukan penambahan fly ash (abu terbang), abu serbuk kayu dan kapur pada tanah tersebut. Penelitian yang nantinya akan diuji adalah:

1. Pemeriksaan Sifat Fisik Tanah 
a) Pemeriksaan kadar air tanah (water content).

b) Percobaan berat volume (volumetric weight).

c) Pemeriksaan berat jenis (spesific gravity).

d) Batas konsistensi tanah (atterberg limit).

e) Pemeriksaan analisis saringan (sieve analysis).

2. Pemeriksaan Sifat Mekanik Tanah

Pemeriksaan sifat mekanik tanah dapat dilakukan dengan cara pemeriksaan kuat geser langsung (direct shear).

\section{Tahap Perencanaan Campuran}

Campuran yang dilakukan pada penelitian ini dengan metode coba - coba yaitu dengan cara tanah lempung dicampur dengan proporsi campuran $0 \%, 5 \%$, dan $15 \%$, Dan benda uji ini akan diperam dengan lama waktu pemeraman 3 hari, dan 7 hari.

\section{Tahap Analisis Data}

Berdasarkan data hasil penelitian yang diperoleh dari hasil pengujian laboratorium kemudian dilakukan analisa untuk masing-masing pengujian sehingga didapatkan sifat fisik tanah lempung. Dan pengujian mekanik tanah untuk tiap sample tanah dengan campuran fly ash, abu serbuk kayu dan kapur.

\section{HASIL \& PEMBAHASAN}

\section{Hasil Pengujian Sifat-Sifat Fisik Tanah}

Tabel 1. Hasil Pemeriksaan Sifat Fisik Tanah

\begin{tabular}{|c|l|c|}
\hline No. & \multicolumn{1}{|c|}{ Jenis Pemeriksaan } & Nilai \\
\hline 1. & Kadar Air (Water Content) \% (W) & 25,09 \\
\hline 2. & Berat Isi Kering (Denisty Test) gr/cm3 $(\gamma \mathrm{d})$ & 1,53 \\
\hline 3. & Berat Jenis (Specific Gravity) (GS) & 2,70 \\
\hline 4. & Batas-Batas Atterberg (\%) & \\
\hline & a. Batas Cair (Liquid Limit) (LL) & 29,65 \\
\hline & b. Batas Plastis (Plastic Limit) (PL) & 15,40 \\
\hline & c. Indeks Plastisitas (Plastic Indeks) (PI) & 14,25 \\
\hline & d. Batas Susut (Shrinkage Limit) (SL) & 15,33 \\
\hline 5. & Analisis Saringan & \\
\hline & a. Persentase Berat Tertahan (\%) & 9,93 \\
\hline & b. Persentase Lolos No.200 (\%) & 51,27 \\
\hline
\end{tabular}

Sumber: Hasil Pemeriksaan Laboratorium (2020)

\section{Klasifikasi Tanah}

\section{Sistem Klasifikasi AASHTO}

Klasifikasi tanah berdasarkan sistem AASHTO mengikuti prosedur sebagai berikut: 
1. Dari hasil pemeriksaan analisis saringan, persentase material lolos saringan No. $200(0,075 \mathrm{~mm})$ adalah $51,27 \%>35 \%$, maka tanah tersebut termasuk dalam klasifikasi lanau-lempung (silt clay), kelompok A-4, A-5, A-6 atau A7.

2. Pemeriksaan batas-batas Atterberg didapat nilai batas cair (LL) $=29,65 \%<$ $40 \%$ dan indeks plastisitas $(\mathrm{PI})=14,25 \%>11 \%$ maka tanah tersebut termasuk kelompok A-6. (Gambar 2)

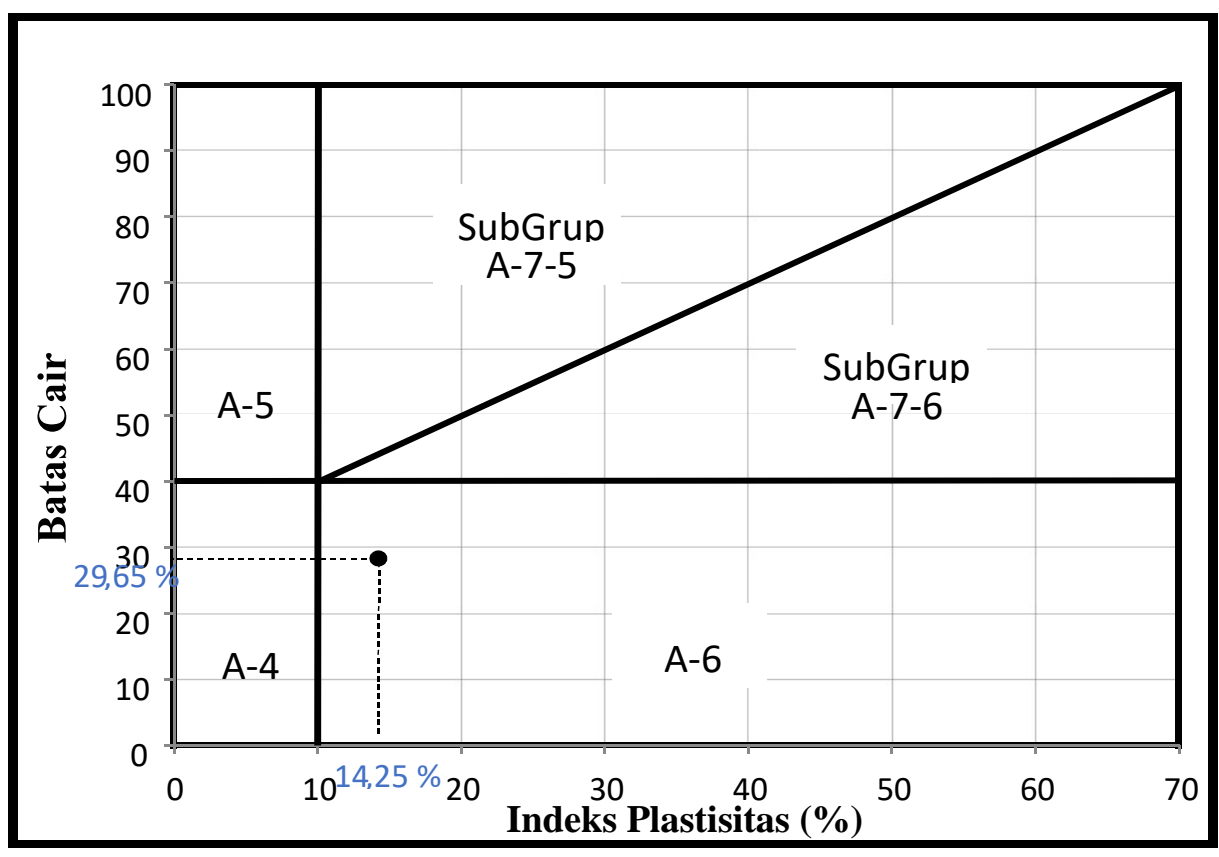

Gambar 2. Klasifikasi Tanah Berdasarkan Sistem Klasifikasi AASHTO

Tabel 2. Klasifikasi Tanah Berdasarkan Tabel Sistem Klasifikasi AASHTO

\begin{tabular}{|c|c|c|c|c|c|c|c|c|}
\hline Umum & Material Grar & lar & $35 \%$ lolos sari & in no.200) & $\begin{array}{c}\text { Tan } \\
(< \\
\end{array}$ & $\begin{array}{l}\mathrm{h} \text { lan: } \\
5 \% \mathrm{l}\end{array}$ & $\begin{array}{l}1 \text { tana } \\
\text { los sa } \\
200)\end{array}$ & $\begin{array}{l}\text { empung } \\
\text { gan no. }\end{array}$ \\
\hline \multirow[b]{2}{*}{$\begin{array}{l}\text { Klasifikasi } \\
\text { Kelompok }\end{array}$} & A1 & \multirow[b]{2}{*}{ A3 } & \multicolumn{2}{|c|}{ A2 } & \multirow[b]{2}{*}{ A-4 } & \multirow[b]{2}{*}{ A-5 } & \multirow[b]{2}{*}{ A- 6} & A-7 \\
\hline & A-1-a A-1-b & & $\begin{array}{c}\text { A-2-4 A-2- } \\
5\end{array}$ & $\begin{array}{c}\text { A-2-6 } \\
27\end{array}$ & & & & $\begin{array}{l}\text { A-7-5 } \\
\text { A-7-6 }\end{array}$ \\
\hline \multicolumn{9}{|l|}{ Analisa Saringan } \\
\hline \multicolumn{9}{|l|}{ ( \% Lolos ) } \\
\hline $\begin{array}{l}2.00 \mathrm{~mm} \\
\text { (no.10) }\end{array}$ & $\begin{array}{c}50 \\
\text { maks }\end{array}$ & - & - & - & - & - & - & - \\
\hline
\end{tabular}

Tabel 2. Lanjutan

\begin{tabular}{|c|c|c|c|c|c|c|c|c|c|c|c|}
\hline $\begin{array}{l}0.425 \mathrm{~mm} \\
\text { (no.40) }\end{array}$ & $\begin{array}{c}30 \\
\text { maks }\end{array}$ & $\begin{array}{c}50 \\
\text { maks }\end{array}$ & $\begin{array}{c}51 \\
\text { maks }\end{array}$ & - & - & - & - & - & - & - & - \\
\hline $\begin{array}{l}0.075 \mathrm{~mm} \\
\text { (no.200) }\end{array}$ & $\begin{array}{c}15 \\
\text { maks }\end{array}$ & $\begin{array}{c}25 \\
\text { maks }\end{array}$ & $\begin{array}{c}10 \\
\text { maks }\end{array}$ & $\begin{array}{c}35 \\
\text { maks }\end{array}$ & $\begin{array}{c}35 \\
\text { maks }\end{array}$ & $\begin{array}{c}35 \\
\text { maks }\end{array}$ & $\begin{array}{c}35 \\
\text { maks }\end{array}$ & $\begin{array}{l}36 \\
\min \end{array}$ & $\begin{array}{l}36 \\
\min \end{array}$ & $\mathbf{5 1 , 2 7}$ & $\begin{array}{c}36 \\
\min \end{array}$ \\
\hline
\end{tabular}


JURNAL KACAPURI

JURNAL KEILMUAN TEKNIK SIPIL

Volume 4 Nomor 1 Edisi Juni 2021

\begin{tabular}{|c|c|c|c|c|c|c|c|c|}
\hline $\begin{array}{l}\text { Sifat Fraksi } \\
\text { Lolos }\end{array}$ & & & & & & & & \\
\hline $\begin{array}{l}\text { Saringan } \\
\text { No. } 40\end{array}$ & & & & & & & & \\
\hline $\begin{array}{l}\text { Batas Cair } \\
\text { (LL) }\end{array}$ & - & - & $\begin{array}{cc}40 & 40 \\
\text { maks } & \text { maks }\end{array}$ & $\begin{array}{cc}40 & 40 \\
\text { maks } & \text { min }\end{array}$ & 29,65 & $\begin{array}{c}40 \\
\min \end{array}$ & 29,65 & $\begin{array}{l}40 \\
\min \end{array}$ \\
\hline $\begin{array}{l}\text { Indeks } \\
\text { Plastis (PI) }\end{array}$ & 6 maks & $\mathrm{Np}$ & $\begin{array}{cc}10 & 10 \\
\text { maks } & \text { maks }\end{array}$ & $\begin{array}{cc}11 & 11 \\
\min & \min \end{array}$ & $\begin{array}{c}10 \\
\text { maks }\end{array}$ & $\begin{array}{c}10 \\
\text { maks }\end{array}$ & 14,25 & $\begin{array}{c}11 \\
\min \end{array}$ \\
\hline $\begin{array}{l}\text { Indeks } \\
\text { Kelompok } \\
\text { (GI) } \\
\end{array}$ & 0 & 0 & 0 & 4 maks & $\begin{array}{c}8 \\
\text { maks }\end{array}$ & $\begin{array}{c}12 \\
\text { maks }\end{array}$ & $\begin{array}{c}6 \\
\text { maks }\end{array}$ & $\begin{array}{c}20 \\
\text { maks }\end{array}$ \\
\hline $\begin{array}{l}\text { Tipe } \\
\text { Material } \\
\text { Yang } \\
\text { Pokok } \\
\text { Pada } \\
\text { Umumnya } \\
\end{array}$ & $\begin{array}{c}\text { Pecahan } \\
\text { Batu, Kerikil } \\
\text { dan Pasir }\end{array}$ & $\begin{array}{l}\text { Pasir } \\
\text { Halus }\end{array}$ & \multicolumn{2}{|c|}{$\begin{array}{l}\text { Kerikil Berlanau atau } \\
\text { Berlempung dan Pasir }\end{array}$} & \multicolumn{2}{|c|}{$\begin{array}{c}\text { Tanah } \\
\text { Berlanau }\end{array}$} & \multicolumn{2}{|c|}{$\begin{array}{l}\text { Tanah } \\
\text { Berlempung }\end{array}$} \\
\hline $\begin{array}{l}\text { Penilaian } \\
\text { Umum } \\
\text { Sebagai } \\
\text { Tanah } \\
\text { Dasar }\end{array}$ & \multicolumn{4}{|c|}{ Sangat Baik Sampai Baik } & \multicolumn{4}{|c|}{ Sedang Sampai Buruk } \\
\hline
\end{tabular}

Kelompok A-6 adalah kelompok tanah berlempung yang masih mengandung butir pasir dan kerikil akan tetapi sifat perubahan volumenya cukup besar. Sehingga sistem klasifikasi ini membagi lagi tanah dalam beberapa kelompok yang setiap kelompoknya dievaluasi terhadap indeks kelompoknya. Perhitungan indeks kelompok (GI) adalah :

$$
\begin{aligned}
\mathrm{GI} & =(\mathrm{F}-35)((0,2+0,005(\mathrm{LL}-40))+0,01(\mathrm{~F}-15)(\mathrm{PI}-10) \\
\mathrm{GI} & =(51,27-35)(0,2+0,005(29,65-40))+0,01(51,27-15)(14,25-10) \\
& =3,95 \approx 4
\end{aligned}
$$

Jadi, tanah diklasifikasikan sebagai tanah berlempung dalam kelompok A-6 (4).

\section{Sistem Klasifikasi USCS}

Klasifikasi tanah berdasarkan sistem USCS mengikuti prosedur sebagai berikut:

1. Dari hasil pemeriksaan analisis saringan, persentase material lolos saringan No.200 $(0,0075 \mathrm{~mm})$ rata-rata $=51,27 \%>50 \%$, maka tanah tersebut termasuk tanah berbutir halus.

2. Dari hasil pemeriksaan batas-batas Atterberg, didapat nilai batas cair (LL) rata-rata $=29,65 \%<50 \%$, maka tanah tersebut termasuk kelompok ML, CL atau OL.

3. Dari grafik batas cair (LL) dan indeks plastisitas (PI) (gambar terlampir) diperoleh LL dan PL yang diplot berada di bawah garis A, maka tanah tersebut termasuk kelompok CL.

4. Secara visual, tanah berwarna kuning dan bercampur dengan sedikit pasir, maka tanah tersebut termasuk dalam kelompok CL.

5. Kelompok CL merupakan kelompok lempung anorganik dengan plastisitas rendah sampai dengan sedang, lempung berkerikil, lempung berpasir, lempung berlanau, lempung "kurus" (lean clays). 
JURNAL KACAPURI

JURNAL KEILMUAN TEKNIK SIPIL

Volume 4 Nomor 1 Edisi Juni 2021

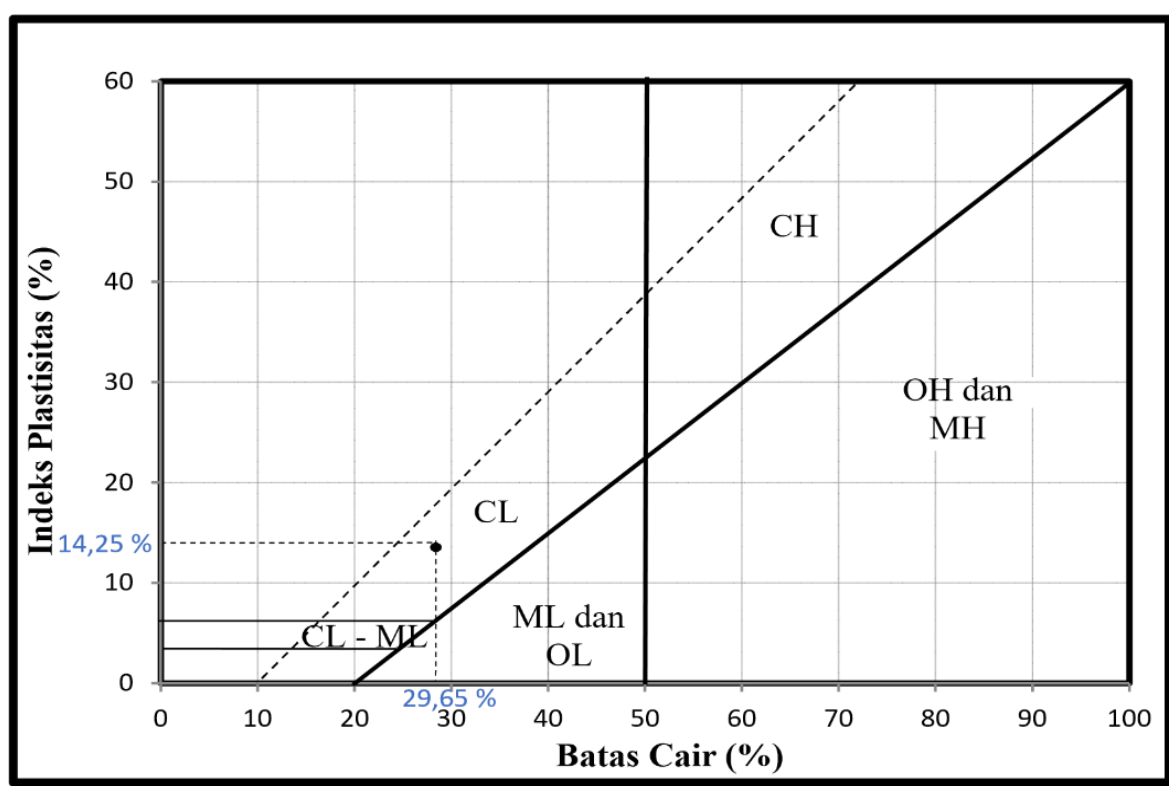

Gambar 3. Klasifikasi Tanah Berdasarkan System Klasifikasi USCS

\section{Hasil Pengujian Sifat-Sifat Mekanik Tanah}

\section{Kuat Geser Tanah}

Kuat geser tanah diperoleh dari hasil uji percobaan geser langsung dimana percobaan geser langsung yang dilakukan yaitu lempung. Berikut adalah tabel pemeriksaan uji geser langsung (direct shear test).

Tabel 3. Pemeriksaan Uji Geser Langsung Pada Jenis Tanah Lempung/Tanah Asli

\begin{tabular}{|c|c|c|c|c|c|c|c|c|c|c|}
\hline $\begin{array}{l}\text { Diametes } \\
\text { Height } \\
\text { Area }\end{array}$ & $\begin{aligned} \text { ampel } & =6 \\
& =2 \\
& =3\end{aligned}$ & $\begin{array}{l}0 \mathrm{~cm} \\
0 \mathrm{~cm} \\
15 \mathrm{~cm}^{2}\end{array}$ & & & \multicolumn{3}{|c|}{ calibration } & 0,5022 & \multicolumn{2}{|c|}{$\mathrm{Kg} / \mathrm{div}$} \\
\hline $\begin{array}{c}\text { Horizontal } \\
\text { Dial }\end{array}$ & Horizontal & $\sigma 1=$ & $\begin{array}{c}=3,167 \\
0,0985 \mathrm{k}\end{array}$ & & $\begin{array}{r}\mathrm{P} 2 \\
\sigma 2=\end{array}$ & $\begin{array}{r}=6,334 \\
1970 \mathrm{k}\end{array}$ & $/ \mathrm{g}$ & $\begin{array}{r}\text { P3 } \\
\sigma 3=\end{array}$ & $\begin{array}{r}=12,668 \\
, 3940 \mathrm{k}\end{array}$ & $\begin{array}{l}\mathrm{kg} \\
/ \mathrm{cm}^{2}\end{array}$ \\
\hline $\begin{array}{c}\text { Reading } \\
\text { (div) }\end{array}$ & $\begin{array}{l}\text { Devormation } \\
(\mathrm{mm})\end{array}$ & $\begin{array}{c}\text { Dial } \\
\text { Reading }\end{array}$ & $\begin{array}{c}\text { Kekuatan } \\
\text { Geser }\end{array}$ & $\begin{array}{c}\tau 1 \\
\mathrm{~kg} / \mathrm{cm}^{2}\end{array}$ & $\begin{array}{c}\text { Dial } \\
\text { Reading }\end{array}$ & $\begin{array}{l}\text { Gaya } \\
\text { Geser }\end{array}$ & $\begin{array}{c}\tau 2 \\
\mathrm{~kg} / \mathrm{cm}^{2} \\
\end{array}$ & $\begin{array}{c}\text { Dial } \\
\text { Reading }\end{array}$ & $\begin{array}{l}\text { Gaya } \\
\text { Geser }\end{array}$ & $\begin{array}{c}\tau 3 \\
\mathrm{~kg} / \mathrm{cm}^{2} \\
\end{array}$ \\
\hline 20 & 0,000 & 1,0 & 0,502 & 0,016 & 3,0 & 1,507 & 0,047 & 1,5 & 0,753 & 0,023 \\
\hline 40 & 2,560 & 1,5 & 0,753 & 0,023 & 7,0 & 3,515 & 0,109 & 9,0 & 4,520 & 0,141 \\
\hline 60 & 3,840 & 3,9 & 1,959 & 0,061 & 13,5 & 6,780 & 0,211 & 16,5 & 8,286 & 0,258 \\
\hline 80 & 5,120 & 7,0 & 3,515 & 0,109 & 17,0 & 8,537 & 0,266 & 18,0 & 9,040 & 0,281 \\
\hline 100 & 6,400 & 9,5 & 4,771 & 0,148 & 17,0 & 8,537 & 0,266 & 19,5 & 9,793 & 0,305 \\
\hline 120 & 7,680 & 11,2 & 5,625 & 0,175 & 17,5 & 8,789 & 0,273 & 20,8 & 10,446 & 0,325 \\
\hline 140 & 8,960 & 12,0 & 6,026 & 0,187 & 18,0 & 9,040 & 0,281 & 21,5 & 10,797 & 0,336 \\
\hline 160 & 10,240 & 12,8 & 6,428 & 0,200 & 17,0 & 8,537 & 0,266 & 22,0 & 11,048 & 0,344 \\
\hline 180 & 11,520 & 13,5 & 6,780 & 0,211 & 17,0 & 8,537 & 0,266 & 22,2 & 11,149 & 0,347 \\
\hline 200 & 12,800 & 14,0 & 7,031 & 0,219 & 17,0 & 8,537 & 0,266 & 22,5 & 11,300 & 0,351 \\
\hline 220 & 14,080 & 14,2 & 7,131 & 0,222 & 17,0 & 8,537 & 0,266 & 22,5 & 11,300 & 0,351 \\
\hline 240 & 15,360 & 14,2 & 7,131 & 0,222 & 17,0 & 8,537 & 0,266 & 21,8 & 10,948 & 0,341 \\
\hline 260 & 16,640 & 14,0 & 7,031 & 0,219 & 16,5 & 8,286 & 0,258 & 21,5 & 10,797 & 0,336 \\
\hline 280 & 17,920 & 13,8 & 6,930 & 0,216 & 16,5 & 8,286 & 0,258 & 21,0 & 10,546 & 0,328 \\
\hline 300 & 19,200 & 13,5 & 6,780 & 0,211 & 16,0 & 8,035 & 0,250 & 20,2 & 10,144 & 0,316 \\
\hline
\end{tabular}

Sumber : Hasil Analisis Data, (2020) 


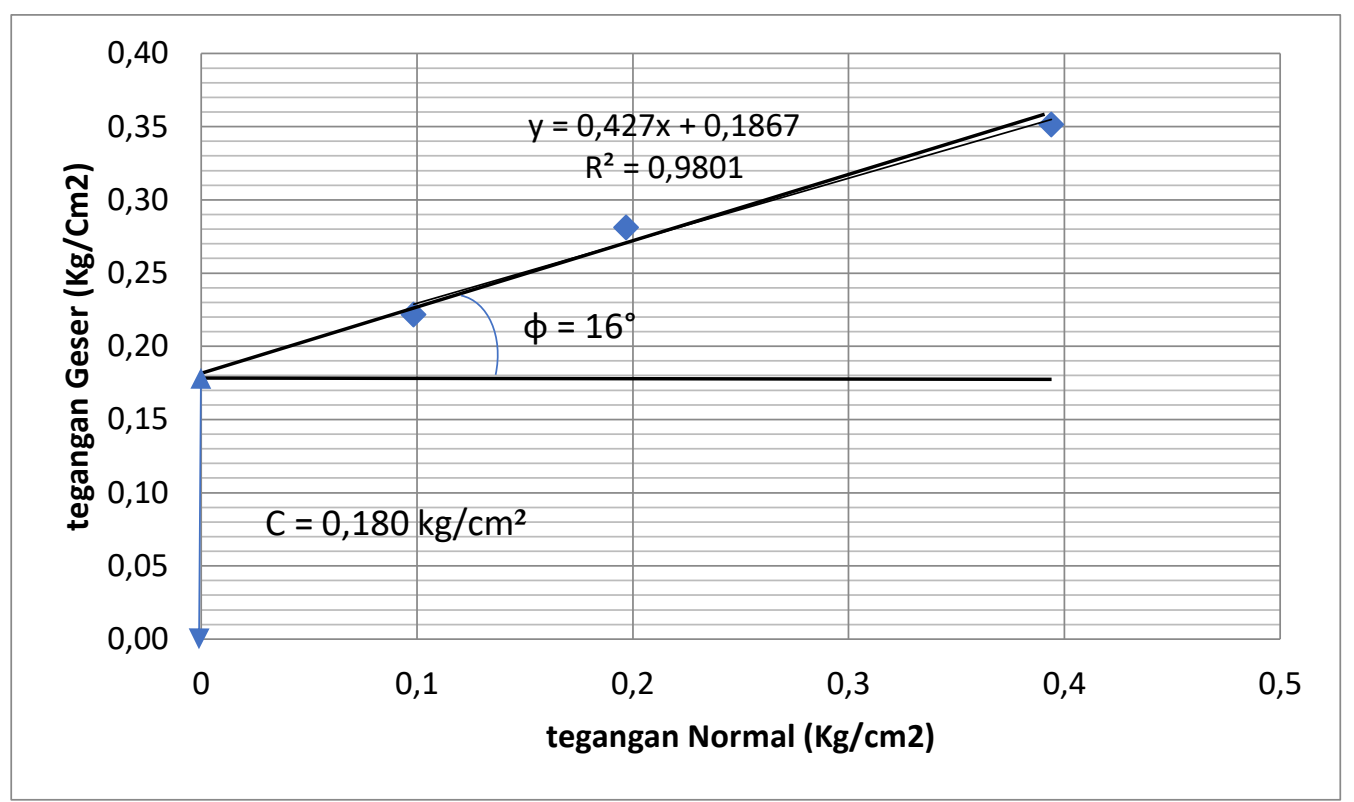

Gambar 4. Grafik Uji Geser Langsung (Direct Shear Test)

Dari gambar 4 uji geser langsung (direct shear test) didapatkan nilai kohesi tanah (c) sebesar $0,180 \mathrm{Kg} / \mathrm{cm} 2$ dan sudut geser tanah $(\varphi)$ sebesar 16 .

\section{Perhitungan Kuat Geser}

Tanah Asli didapatkan nilai kohesi tanah (c) sebesar $0,180 \mathrm{Kg} / \mathrm{cm}^{2}$ dan sudut geser tanah $(\varphi)$ sebesar 16.

Jadi kuat geser tanah :

$(\tau) c+\sigma \operatorname{tg} \varphi=0,180+0,153 \operatorname{tg}(16)$

$$
=0,223
$$

$* \sigma=\gamma . \mathrm{H}$

$$
=1,53 \times 100 \mathrm{~cm}=153=0,153 \text {. }
$$

$(\tau) c+\sigma \operatorname{tg} \varphi=0,185+0,153 \operatorname{tg}(16)$

$$
=0,228
$$

Dari hasil hitungan di atas di dapatkan :

Tabel 4. Rekapitulasi Pengujian Kuat Geser

\begin{tabular}{|l|c|c|c|}
\hline \multicolumn{1}{|c|}{ Sampel } & $\begin{array}{c}\text { Kohesi } \\
(\mathrm{C})\end{array}$ & $\begin{array}{c}\text { Sudut Geser } \\
\text { Tanah }(\varnothing)\end{array}$ & $\begin{array}{c}\text { Kuat geser } \\
(\tau)\end{array}$ \\
\cline { 2 - 4 } & $\mathrm{Kg} / \mathrm{cm}^{2}$ & $\left(\begin{array}{c}\mathbf{0} \\
)\end{array}\right.$ & $\mathrm{Kg} / \mathrm{cm}^{2}$ \\
\hline Tanah Asli & 0,180 & $16^{\circ}$ & 0,223 \\
\hline \multicolumn{3}{|c|}{ TANAH CAMPURAN FLY ASH, ABU SERBUK DAN KAPUR $(3$ Hari $)$} \\
\hline $\begin{array}{l}\text { Tanah Asli + fly ash 5\%, abu serbuk } \\
\text { kayu + kapur }\end{array}$ & 0,185 & $16^{\circ}$ & 0,228 \\
\hline $\begin{array}{l}\text { Tanah Asli + fly ash, abu serbuk kayu } \\
\text { 5\% + kapur }\end{array}$ & 0,198 & $19^{\circ}$ & 0,250 \\
\hline
\end{tabular}


Tabel 4. Lanjutan

\begin{tabular}{|l|c|c|c|}
\hline \multicolumn{1}{|c|}{ Sampel } & $\begin{array}{c}\text { Kohesi } \\
(\mathrm{C})\end{array}$ & $\begin{array}{c}\text { Sudut Geser } \\
\text { Tanah }(\varnothing)\end{array}$ & $\begin{array}{c}\text { Kuat geser } \\
(\tau)\end{array}$ \\
\cline { 2 - 4 } & $\mathrm{Kg} / \mathrm{cm}^{2}$ & $\left({ }^{\circ}\right)$ & $\mathrm{Kg} / \mathrm{cm}^{2}$ \\
\hline $\begin{array}{l}\text { Tanah Asli + fly ash, abu serbuk kayu + } \\
\text { kapur 15\% }\end{array}$ & 0,22 & $20^{\circ}$ & 0,275 \\
\hline TANAH CAMPURAN FLY ASH, ABU SERBUK DAN KAPUR (7 Hari)
\end{tabular}

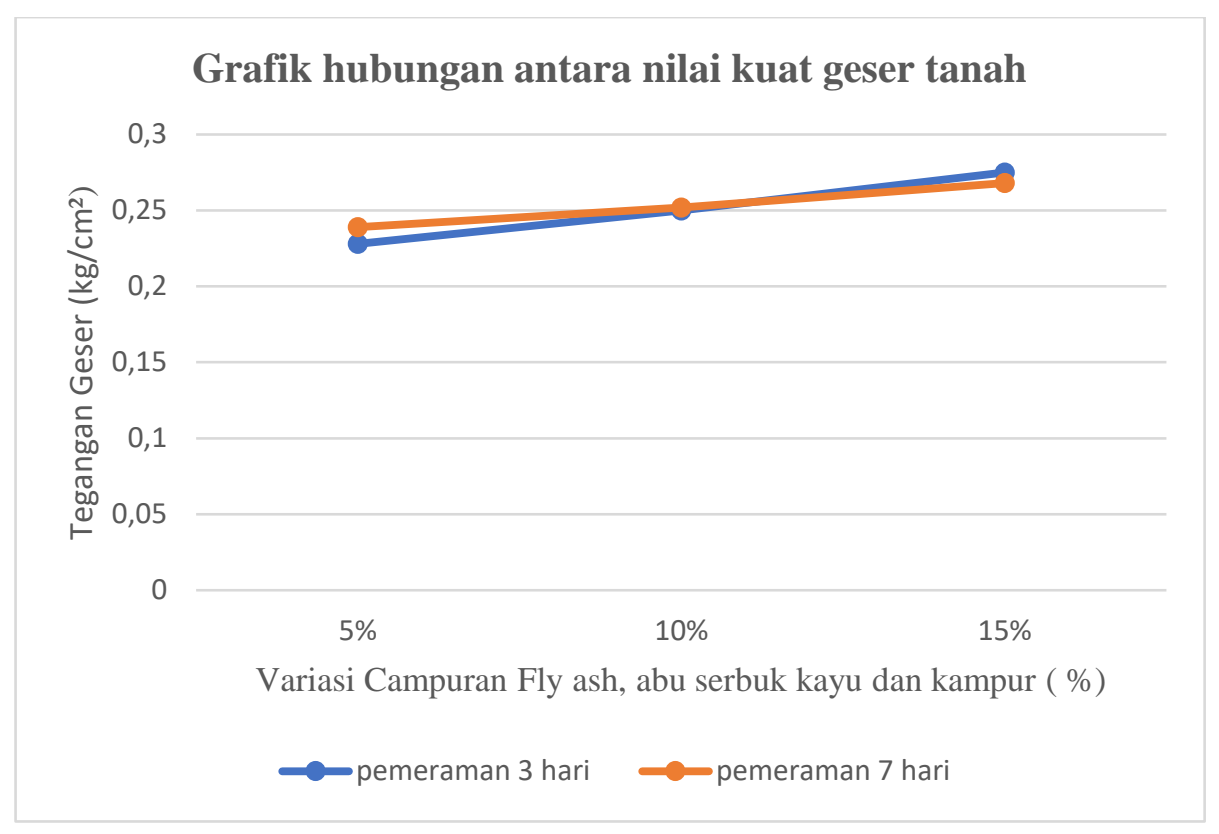

Gambar 5. Grafik Hubungan Nilai Kuat Geser Tanah Pemeraman 3 Hari dan 7 Hari

\section{Perhitungan Daya Dukung Tanah}

Perhitungan Qult Tanah Asli :

Qult $=$ C.Nc + o. $. \mathrm{Nq}+0,5$. B. $\gamma \cdot \mathrm{N} \gamma$

$\mathrm{C} \quad=0,180 \mathrm{~kg} / \mathrm{cm} 2$

Berdasarkan sudut $\phi 16^{\circ}$ di dapat :

$$
\begin{aligned}
& \mathrm{Nc}=13,68 \quad \rho \mathrm{o}=\gamma \cdot \mathrm{H}=0,153 \mathrm{~kg} / \mathrm{cm}^{2} \\
& \mathrm{Nq}=4,92 \quad \mathrm{~B}=100 \mathrm{~cm} \\
& \mathrm{~N} \gamma=1,82 \quad \gamma=0,00153 \\
& \text { Qult }=0,180.13,68+0,153.4,92+0,5.100 .0,00153.1,82 \\
& =3,354 \mathrm{~kg} / \mathrm{cm}^{2}
\end{aligned}
$$


Dari Perhitungan diatas di dapatkan Tabel 5.

Table 5. Rekapitulasi Perhitungan Daya Dukung

\begin{tabular}{|c|c|c|c|}
\hline Sudut Geser( $\varnothing)$ & Kuat geser & $\begin{array}{c}\text { Daya Dukung } \\
(\text { Qult })\end{array}$ & Q ijin $=\frac{\text { Qult }}{3}$ \\
\hline$\left({ }^{\mathbf{o}}\right)$ & $(\tau)$ & $\mathrm{Kg} / \mathrm{cm}^{2}$ & $\mathrm{Kg} / \mathrm{cm}^{2}$ \\
\hline $16^{0}$ & 0,223 & 3,354 & 1,108 \\
\hline $16^{\mathbf{o}}$ & 0,228 & 3,422 & 1,140 \\
\hline $19^{\mathbf{o}}$ & 0,250 & 4,773 & 1,159 \\
\hline $20^{\mathbf{o}}$ & 0,275 & 5,308 & 1,769 \\
\hline $18^{\mathbf{o}}$ & 0,239 & 3,995 & 1,331 \\
\hline $19^{\circ}$ & 0,252 & 4,903 & 1,634 \\
\hline $21^{\mathbf{o}}$ & 0,268 & 5,945 & 1,981 \\
\hline
\end{tabular}

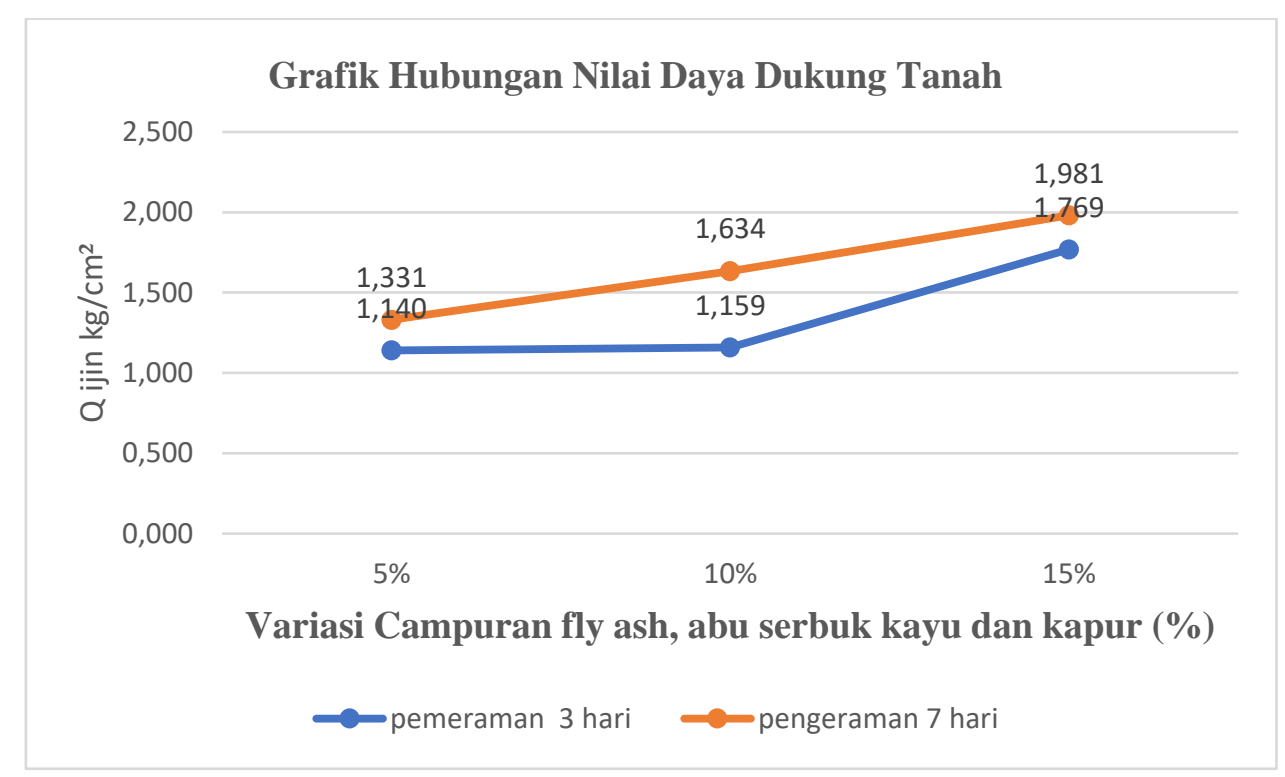

Gambar 6. Grafik Hubungan Nilai Daya Dukung Tanah Pemeraman 3 Hari dan 7 Hari

\section{Kesimpulan}

\section{PENUTUP}

Berdasarkan hasil penelitian dilakukan untuk mengetahui sifat fisik dan mekanik tanah lempung pada Desa Bukit Rawi Kecamatan Kahayan, Kabupaten Pulang Pisau, Kalimantan Tengah maka kesimpulan :

1. Hasil pengujian sifat-sifat fisik tanah dan mekanik tanah untuk sampel tanah dari daerah Desa Bukit Rawi, Kecamatan Kahayan Tengah, Kabupaten Pulang Pisau, Kalimantan Tengah diperoleh nilai, kadar air sebesar $=25,09 \%$; berat isi $=1,53$ $\mathrm{gr} / \mathrm{cm} 3$; berat jenis $=2,70 \%$; batas-batas atterberg, $\mathrm{LL}=29,65 \% ; \mathrm{PL}=15,40$ $\%$; PI $=14,25 \%$; SL $=15,33 \%$; analisis saringan meliputi persentase berat material tertahan $=9,93 \%$; persentase lolos saringan $=51,27 \%$; Jenis dan karakteristik tanah menurut USCS dari hasil pemeriksaan analisa saringan untuk tanah lempung, presentase material lolos saringan No. 200 adalah 51,27\% >50\% 
dan pemeriksaan batas-batas Atterberg didapat nilai LL $=29,65 \%<50 \%$. Berdasarkan sistem klasifikasi menurut AASHTO tanah ini termasuk kedalam kelompok A-6 (4) yang di klasifikasikan tanah yang masih mengandung butir butir pasir dan kerikil, untuk system klasifikasi menurut USCS tanah tergolong dalam kelompok CL yaitu tanah lempung anorganik dengan plastisitas rendah sampai dengan sedang, lempung berkerikil, lempung berpasir lempung berlanau, lempung "kurus" (lean clays).

2. Proporsi campuran terhadap daya dukung tanah lempung yaitu fly ash 5\%, abu serbuk kayu 5\% dan kapur 15\%. Tanah Asli + fly ash 5\% , abu serbuk kayu + kapur pemeraman selama 3 hari di dapatkan hasil 0,228 kg/cm2, Tanah Asli + fly ash, abu serbuk kayu 5\% + kapur pemeraman selama 3 hari di dapatkan hasil 0,250 kg/cm2, fly ash + abu serbuk kayu + kapur 15\% pemeraman selama 3 hari di dapatkan hasil $0,275 \mathrm{~kg} / \mathrm{cm} 2$. Kemudian Hasil pemeraman 7 hari di dapatkan Tanah Asli + fly ash 5\%, abu serbuk kayu + kapur pemeraman selama 7 hari di dapatkan hasil $0,239 \mathrm{~kg} / \mathrm{cm} 2$, Tanah Asli + fly ash, abu serbuk kayu $5 \%+$ kapur pemeraman selama 7 hari di dapatkan hasil $0,252 \mathrm{~kg} / \mathrm{cm} 2$, fly ash + abu serbuk kayu + kapur 15\% pemeraman selama 7 hari di dapatkan hasil 0,268 $\mathrm{kg} / \mathrm{cm} 2$

3. Pengaruh penggunaan fly ash, abu serbuk kayu dan kapur terhadap kuat geser dan daya dukung tanah ialah : Peningkatan nilai sudut geser tanah $(\varnothing)$ tertinggi pada fly ash, abu serbuk kayu dan kapur 3 hari terdapat pada persentase campuran tanah $15 \%$ sebesar $=20^{\circ}$ dengan persentase kenaikan sebesar $=5,2 \%$ dari tanah asli dan pada fly ash, abu serbuk kayu dan kapur 7 hari pada campuran $15 \%$ sebesar $=21^{\circ}$ dengan persentase sebesar 2,9\% dari tanah asli. Sedangkan peningkatan nilai kohesi (c) tertinggi fly ash, abu serbuk kayu dan kapur 3 hari terdapat pada persentase campuran $10 \%$ sebesar $=0,198 \mathrm{~kg} / \mathrm{cm} 2$ dengan persentase kenaikan sebesar $=0,8 \%$ dari tanah asli dan pada fly ash, abu serbuk kayu dan kapur 7 hari pada campuran $15 \%$ sebesar $=0,23 \mathrm{~kg} / \mathrm{cm} 2$ dengan persentase sebesar $=4 \%$ dari tanah asli. Pengujian kuat geser dengan penambahan fly ash, abu serbuk kayu dan kapur pada tanah lempung dapat meningkatkan nilai sudut geser tanah dan nilai kohesi.

\section{Saran}

Untuk menindak lanjuti penelitian ini kiranya perlu dilakukan beberapa koreksi agar penelitian ini selanjutnya lebih baik lagi. Adapun saran-saran untuk penelitian selanjutnya antara lain:

1. Saran terhadap penelitian ini adalah untuk mengetahui efektif atau tidaknya campuran fly ash, abu serbuk kayu dan kapur, perlu diteliti lebih lanjut sehingga akan diketahui nilai nyata terjadinya perubahan akibat pengaruh penambahaan bahan tersebut. Agar lebih teliti pada saat pembuatan sampel dan pembacaan dial supaya didapat hasil yang maksimal.

2. Perlu diadakan pengujian kuat geser pembanding dengan peralatan lain misalnya: Alat Uji Triaksial dan Tekan Bebas. 


\section{DAFTAR PUSTAKA}

1. Google Earth. 2020. Google Earth: Peta Lokasi Desa Bukit Rawi, Kecamatan Kahayan Tengah, Kabupaten Pulang Pisau, Kalimantan Tengah.

2. Agung, Hendri. 2014. Studi Pengaruh Pertambahan Serat Serabut Kelapa Terhadap Nilai Stabilitas Tanah Lempung Pada Pengujian Kuat Geser. Teknik Sipil. Fakultas Teknik. Universitas Palangka Raya.

3. Anita. 2010. Stabilisasi Tanah Lempung Batola Menggunakan Campuran Limbah Karbit dan Abu Batubara. Teknik Sipil. Fakultas Teknik. Universitas Palangka Raya.

4. Wahyuni, Ida. 2004. Penggunaan Batu Kapur Sebagai Bahan Alternatif Stabilitas Tanah Dasar. Teknik Sipil. Fakultas Teknik. Universitas Palangka Raya.

5. Prasenda, Christian, Setyanto, dan Iswan. 2015. Pengaruh Penambahan Pasir Terhadap Tingkat Kepadatan dan Daya Dukung Tanah Lempung Lunak. JRSDD, Vol 3(1): 91-102

6. Wesley, L. D. 1973. Mekanika Tanah. Jakarta : Badan Penerbit Pustaka Umum. 